\title{
GH deficiency and insensitivity in children and adults
}

\author{
Gudmundur Johannsson $^{1,2}$ (D) · John J. Kopchick ${ }^{1,2}$ \\ Accepted: 15 January 2021 / Published online: 10 February 2021 \\ (C) The Author(s) 2021
}

\begin{abstract}
This thematic review includes short reviews on GH deficiency and insensitivity in children and adults from basic science to clinical significance.
\end{abstract}

Keywords Growth hormone · IGF-I - Growth • Growth hormone deficiency · Growth hormone receptor · IGF-I receptor · Pharmacogenomics

We are proud to present this thematic review on growth hormone $(\mathrm{GH})$ deficiency and insensitivity in children and adults. It contains short reviews made by eminent experts in the field that together comprises a comprehensive assessment of the field from basic science to clinical significance.

The activity of the GH-IGF-I axis is regulated by the amount and secretory pattern of the $\mathrm{GH}$, the endocrine and paracrine/autocrine production of IGF-I and the interaction of GH and IGF-I at the tissue specific level. Additionally, GH and IGF-1 have both unique and overlapping actions related to growth and metabolism. Therefore, overall effects of the GHIGF-axis on growth and metabolism is dependent on the amount of GH and IGF-I at the tissue level as well as the responsiveness/sensitivity of the GH and IGF-I receptors.

Through clinical observation and experience, clinicians have observed variable responses to $\mathrm{GH}$ treatment in children. For example, the same GH exposure can produce a highly variable magnitude of growth. Similarly in adults, GH replacement in patients with hypopituitarism and severe $\mathrm{GH}$ deficiency can produce a response that is highly variable. In adults the efficacy of GH replacement varies from changes in body composition and lipid profile to improvement in wellbeing and quality of life. Additionally, it is also unpredictable

Gudmundur Johannsson

gudmundur.johannsson@medic.gu.se

1 Institute of Medicine, Sahlgrenska Academy, University of Gothenburg, Gothenburg, Sweden

2 Edison Biotechnology Institute, Ohio University, Athens, OH, USA to which of these endpoints an individual subject seems to respond most.

The aim of this thematic issue was therefore to shed light on the clinical aspects related to GH deficiency and insensitivity in both children and adults. This issue also includes human models of extreme $\mathrm{GH}$ insensitivity induced by inactivating changes in the $\mathrm{GH}$ receptor as well as at the post receptor level. The careful phenotyping as well as the molecular discoveries in these patients have extended the findings on the physiology of the GH-IGF-I axis and some of the individual sensitivities attributed to either GH or IGF-I. These observations have also been useful in better understanding the consequences of long-standing GH deficiency in children and adults. In addition to human studies, animal models of GH deficiency and insensitivity have also improved our understanding on the impact of GH and/or IGF-1 on tissue specific metabolism and in the end its impact on health- and life-span. Related to this is the findings in adults with GH deficiency that showed reduced survival in the unreplaced state. The causal relationship with $\mathrm{GH}$ deficiency has been debated and is further reviewed and discussed in this thematic issue.

The clinical challenges in the diagnosis of GH deficiency and various degree of insensitivity are further discussed together with strategies to improve outcome among these patients. With a perfect mix between basic, translational and clinical topics related to GH deficiency and insensitivity, we hope that the readers of this issue will enjoy and appreciate the science behind the short reviews. We also hope that the reader 
will improve their understanding of the molecular mechanism(s) of GH/IGF-1 action, the clinical consequences and the treatment strategies to improve each patient's outcome from childhood to adulthood.Funding Open Access funding provided by University of Gothenburg.

\section{Declarations}

Conflict of interest No conflict of interest in relation to this work.

Open Access This article is licensed under a Creative Commons Attribution 4.0 International License, which permits use, sharing, adaptation, distribution and reproduction in any medium or format, as long as you give appropriate credit to the original author(s) and the source, provide a link to the Creative Commons licence, and indicate if changes were made. The images or other third party material in this article are included in the article's Creative Commons licence, unless indicated otherwise in a credit line to the material. If material is not included in the article's Creative Commons licence and your intended use is not permitted by statutory regulation or exceeds the permitted use, you will need to obtain permission directly from the copyright holder. To view a copy of this licence, visit http://creativecommons.org/licenses/by/4.0/.

Publisher's note Springer Nature remains neutral with regard to jurisdictional claims in published maps and institutional affiliations. 